\title{
PECULIARITIES OF MOTOR FITNESS STRUCTURE OF 9-YEAR-OLD GIRLS
}

\author{
Oleg Khudolii ${ }^{1 \mathrm{ABCD}}$, Vladyslav Golovnin ${ }^{\mathrm{ABCD}}$, Pavol Bartik ${ }^{\mathrm{ABCD}}$ \\ ${ }^{1}$ H. S. Skovoroda Kharkiv National Pedagogical University \\ ${ }^{2}$ Matej Bel University \\ Authors' Contribution: A - Study design; B - Data collection; C - Statistical analysis; D - Manuscript Preparation; E - Funds Collection
}

DOI: $10.17309 / \mathrm{jltm} .2020 .2 .01$

\begin{abstract}
Purpose. To determine the peculiarities of 9-year-old girls' motor fitness structure.

Materials and methods. The study involved 35 9-year-old girls. The children and their parents were informed about all the features of the study and gave their consent to participate in the experiment. The study used the following research methods: analysis of scientific and methodological literature, pedagogical observations, testing of motor fitness, probabilistic approach to assessing the learning process, methods of mathematical statistics.

Results. The level of fitness of the 9-year-old girls is homogeneous by the development of "agility" and "movement coordination", inhomogeneous - by the development of flexibility, arm strength, vestibular stability, and the level of proficiency in gymnastic exercises. A graphic representation of a two-factor model of testing results shows that the analysis identifies two sets of data with high correlation coefficients. The first set includes tests No. 12, 13, 14, and 7, which characterize the level of proficiency in gymnastic exercises and relative arm strength; the second - tests No. 1, 10, and 5, which characterize the level of movement coordination development.

Conclusions. Based on factor analysis, it was found that the level of proficiency in exercises determines the variation of testing results by $28.394 \%$, and the development of motor skills is a priority in the educational process at primary school.

The level of proficiency in gymnastic exercises shows that the exercises "Rope climbing in two steps", "Rope climbing in three steps", "One leg swing upward circle" are difficult for 9-year-old girls to perform. Based on the data analysis, it can be argued that the development of "arm strength" and "vestibular stability" ensures the formation of motor skills, and the improvement of their development level is the reserve in training girls aged 9 which will positively influence the formation of motor skills.
\end{abstract}

Keywords: 9-year-old girls, level of proficiency, motor fitness, motor skills.

\section{Introduction}

The importance of increasing schoolchildren's motor activity is pointed out by Krutsevich, Pengelova, and Trachuk (2019), Krutsevich, and Marchenko (2018). Motor activity is viewed as a condition for physical development and formation of cognitive functions (Junger, Salonna, Bergier, Junger, Frömel, Ács, \& Bergier, 2019), Haverkamp, Wiersma, Vertessen, van Ewijk, Oosterlaan, and Hartman (2020).

Studies focus on substantiating the amount of motor activity (Kondakov, Voloshina, Kopeikina, \& Kadutskaya, 2020); studying the impact of physical exercises on human cognitive functions (Quaney, Boyd, McDowd, Zahner, He, Mayo, \& Macko, 2009); developing a technique for teaching physical exercises (Khudolii, Kapkan, Harkusha, Marchenko, \& Veremeenko, 2020); a technique for motor abilities development in schoolchildren (Ivashchenko, Khudolii, Prusik, \& Giovanis, 2020).

(C) Khudolii, O., Golovnin, V., Bartik, P., 2020.
It was found that the positive effect of learning depends on the level of motor abilities development, consistent solving of learning tasks, and rational application of methods (Khudolii, 2019; Ivashchenko, 2020).

However, further research is needed to determine the leading role of motor skills development in the educational environment at primary school.

The study purpose was to determine the peculiarities of 9 -year-old girls' motor fitness structure.

\section{Materials and methods}

\section{Study Participants}

The study involved 35 9-year-old girls. The children and their parents were informed about all the features of the study and gave their consent to participate in the experiment. 


\section{Organization of the Study}

The study used the following research methods: analysis of scientific and methodological literature, pedagogical observations, testing of motor fitness, probabilistic approach to assessing the learning process, methods of mathematical statistics.

The study recorded the indicators of height $(\mathrm{cm})$, body weight $(\mathrm{kg})$, as well as the results in tests No. 3 "Standing long jump (cm)", No. 4 "Middle- and long-distance running. $300 \mathrm{~m}$ running (s)", No. 5 "30 m sprint running from a standing start (s)", No. 6 "Seated forward bend (cm)", No. 7 "Mixed hang rope pull-ups (times)", No. 8 "Shuttle run $4 \times 9$ m (s)", No. 9 "Combined movements of arms, torso and legs (points)", No. 10 "Maintenance of stable posture - standing on one leg with closed eyes (s)", No. 11 "Walking along straight line after 5 rotations (deviations in $\mathrm{cm}$ )".

The study recorded the primary schoolchildren's level of proficiency in gymnastic exercises. The coefficient was determined by the formula: $\mathrm{p}=(\mathrm{m} / \mathrm{n}) \times 100$, where $\mathrm{p}$ is the level of proficiency, $\mathrm{m}$ is the number of successfully performed exercises, $\mathrm{n}$ is the total number of attempts to perform the exercise. In the experiment, the study controlled the level of proficiency in the following exercises: "Rope climbing in two steps", "Rope climbing in three steps", "One leg swing upward circle".

\section{Statistical Analysis}

The study materials were processed using the IBM SPSS 20 statistical analysis software. Factor analysis was performed. In the factor analysis, the study used the model of principal components with the rotation method: Varimax with Kaiser Normalization.

The study protocol was approved by the Ethical Committee of the University. In addition, the children and their parents or legal guardians were fully informed about all the features of the study, and a signed informed-consent document was obtained from all the parents.

\section{Results}

Table 1 shows the results of testing the 9-year-old girls' motor fitness.

The analysis of the coefficients of variation of testing results showed that the 9-year-old girls' fitness is homogeneous by the following tests No. 1 "Height, cm" (3.67\%); No. 5 "30 $\mathrm{m}$ running from a standing start, s" (4.71\%); No. 8 "Shuttle run $4 \times 9$ m, s" (5.78\%); No. 9 "Combined movements of arms, torso and legs, points" (8.64\%); No. 3 "Standing long jump, cm" (10.92\%); No. 4 "300 m running, s" (14.14\%); No. 2 "Body weight, kg” (17.75\%).

The inhomogeneity in the level of the girls' fitness is observed in the results of tests: No. 6 "Seated forward bend, cm" (37.04\%); No. 10 "Maintenance of stable posture - standing on one leg with closed eyes, s" (56.61\%); No. 7 "Mixed hang rope pull-ups, times" (57.89\%); No. 11 "Walking along straight line after 5 rotations, deviations in cm" (73.54\%).

The coefficient of variation in terms of the level of proficiency in the exercises "Rope climbing in two steps, level of proficiency" (87.5\%); "Rope climbing in three steps, level of proficiency" (90.65\%); "One leg swing upward circle, level of proficiency" (93.23\%) shows that the exercises are difficult to perform.
Table 1. The results of testing the 9-year-old girls' motor fitness $(\mathrm{n}=35)$

\begin{tabular}{|c|c|c|c|c|}
\hline No. & Tests & $\mathbf{X}$ & $\mathbf{s}$ & $\mathrm{V}, \%$ \\
\hline 1 & Height, $\mathrm{cm}$ & 133.6 & 4.9 & 3.67 \\
\hline 2 & Body weight, kg & 32.1 & 5.7 & 17.75 \\
\hline 3 & Standing long jump, $\mathrm{cm}$ & 119.0 & 13.0 & 10.92 \\
\hline 4 & $300 \mathrm{~m}$ running, $\mathrm{s}$ & 113.9 & 16.1 & 14.14 \\
\hline 5 & $30 \mathrm{~m}$ running from a standing start, $\mathrm{s}$ & 6.8 & 0.32 & 4.71 \\
\hline 6 & Seated forward bend, $\mathrm{cm}$ & 8.1 & 3.0 & 37.04 \\
\hline 7 & Mixed hang rope pull-ups, times & 1.9 & 1.1 & 57.89 \\
\hline 8 & Shuttle run $4 \times 9 \mathrm{~m}, \mathrm{~s}$ & 12.8 & 0.74 & 5.78 \\
\hline 9 & $\begin{array}{l}\text { Combined movements of arms, } \\
\text { torso and legs, points }\end{array}$ & 8.1 & 0.7 & 8.64 \\
\hline 10 & $\begin{array}{l}\text { Maintenance of stable posture - } \\
\text { standing on one leg with closed } \\
\text { eyes, s }\end{array}$ & 18.9 & 10.7 & 56.61 \\
\hline 11 & $\begin{array}{l}\text { Walking along straight line after } 5 \\
\text { rotations, deviations in } \mathrm{cm}\end{array}$ & 88.8 & 65.3 & 73.54 \\
\hline 12 & $\begin{array}{l}\text { Rope climbing in two steps, level of } \\
\text { proficiency }\end{array}$ & 24.0 & 21.0 & 87.5 \\
\hline 13 & $\begin{array}{l}\text { Rope climbing in three steps, level of } \\
\text { proficiency }\end{array}$ & f 24.6 & 22.3 & 90.65 \\
\hline 14 & $\begin{array}{l}\text { One leg swing upward circle, level of } \\
\text { proficiency }\end{array}$ & 25.1 & 23.4 & 93.23 \\
\hline
\end{tabular}

Thus, the level of fitness of the 9-year-old girls is homogeneous by the development of "agility" and "movement coordination", inhomogeneous - by the development of flexibility, arm strength, vestibular stability, and the level of proficiency in gymnastic exercises.

Table 2 shows the results of factor analysis. The analysis identified five factors that explain $74.773 \%$ of the variation of results.

The first factor has a weight of $28.394 \%$. With the factor, the greatest correlation is in the level of proficiency in exercises: No. 12 "Rope climbing in two steps, level of proficiency" ( $r=0.983)$; No. 13 "Rope climbing in three steps, level of proficiency" ( $\mathrm{r}=0.984)$; No.14 "One leg swing upward circle, level of proficiency" ( $r=0.987)$. The factor is called the level of proficiency in gymnastic exercises.

The second factor has a weight of $15.346 \%$. With the factor, the greatest correlation is in: No. 1 "Height, $\mathrm{cm}$ " ( $r=0.843)$; No. 2 "Body weight, kg" ( $r=0.816)$; No. 8 "Shuttle run $4 \times 9$ m, s" $(r$ $=0.688$ ). The factor is called physical development.

The third factor has a weight of $11.567 \%$. With the factor, the greatest correlation is in: No. 5 "30 m running from a standing start, s" ( $r=0.833)$; No. 4 "300 m running, s" $(r=0.722)$; No. 10 "Maintenance of stable posture - standing on one leg with closed eyes, $s$ " $(r=0.438)$. The factor is called the level of general physical fitness.

The fourth factor has a weight of $10.608 \%$. With the factor, the greatest correlation is in: No. 3 "Standing long jump, cm" ( $r=0.731)$; No. 11 "Walking along straight line after 5 rotations, deviations in cm" ( $r=-0.694)$; No. 10 "Maintenance of stable posture - standing on one leg with closed eyes, $s$ " $(r=0.482)$. The factor is called vestibular stability.

The fifth factor has a weight of $8.858 \%$. With the factor, the greatest correlation is in tests: No. 9 "Combined movements of arms, torso and legs, points" ( $r=0.820)$; No. 6 "Seated forward bend, $\mathrm{cm}$ " $(r=-0.599)$. The factor is called movement coordination. 
Table 2. The results of factor analysis. Girls aged $9(n=35)$

\begin{tabular}{|c|c|c|c|c|c|c|c|}
\hline \multirow{2}{*}{ No. } & \multirow{2}{*}{ Test } & \multicolumn{5}{|c|}{ Factor } & \multirow[t]{2}{*}{$\mathbf{h}^{2}$} \\
\hline & & 1 & 2 & 3 & 4 & 5 & \\
\hline 1 & Height, $\mathrm{cm}$ & & 0.843 & & & & 0.821 \\
\hline 2 & Body weight, $\mathrm{kg}$ & & 0.816 & & & & 0.715 \\
\hline 3 & Standing long jump, $\mathrm{cm}$ & & & & 0.731 & & 0.719 \\
\hline 4 & $300 \mathrm{~m}$ running, s & -0.330 & & 0.722 & & & 0.675 \\
\hline 5 & $30 \mathrm{~m}$ running from a standing start, $\mathrm{s}$ & & & 0.833 & & & 0.755 \\
\hline 6 & Seated forward bend, $\mathrm{cm}$ & & -0.346 & & & -0.599 & 0.628 \\
\hline 7 & Mixed hang rope pull-ups, times & 0.920 & & & & & 0.858 \\
\hline 8 & Shuttle run $4 \times 9 \mathrm{~m}, \mathrm{~s}$ & & 0.688 & & & & 0.508 \\
\hline 9 & Combined movements of arms, torso and legs, points & & & & & 0.820 & 0.772 \\
\hline 10 & $\begin{array}{l}\text { Maintenance of stable posture - standing on one leg with } \\
\text { closed eyes, } s\end{array}$ & & & 0.438 & 0.482 & & 0.538 \\
\hline 11 & Walking along straight line after 5 rotations, deviations in $\mathrm{cm}$ & & & & -0.694 & & 0.551 \\
\hline 12 & Rope climbing in two steps, level of proficiency & 0.983 & & & & & 0.972 \\
\hline 13 & Rope climbing in three steps, level of proficiency & 0.984 & & & & & 0.978 \\
\hline \multirow[t]{2}{*}{14} & One leg swing upward circle, level of proficiency & 0.987 & & & & & 0.978 \\
\hline & $\%$ & 28.394 & 15.346 & 11.567 & 10.608 & 8.858 & 74.773 \\
\hline
\end{tabular}

The analysis of similarities made it possible to identify the most informative indicators that determine the level of motor fitness of the 9-year-old girls:

- No. 12 "Rope climbing in two steps, level of proficiency" $(r=0.972)$;

- No. 13 "Rope climbing in three steps, level of proficiency" ( $r=0.978)$;

- No. 14 "One leg swing upward circle, level of proficiency" $(r=0.978)$;

- $\quad$ No. 7 "Mixed hang rope pull-ups, times" ( $r=0.858)$.

The graphic representation of a two-factor model of testing results shows that the analysis identifies two sets of data with high correlation coefficients. The first set includes tests No. 12,13, 14, and 7, which characterize the level of proficiency in gymnastic exercises and relative arm strength; the second - tests No. 1, 10, and 5, which characterize the level of movement coordination development (see Fig. 1).

Thus, the motor fitness of 9-year-old girls is determined by the level of development of arm strength, vestibular stability, and the level of proficiency in gymnastic exercises.

\section{Discussion}

The paper assumed that motor skills occupy a prominent place in the structure of motor fitness of 9-year-old girls. So, the level of proficiency in exercises determines the variation of testing results by $28.394 \%$. Thus, the study's findings make it possible to accept the research hypothesis on the leading role of motor skills development in the educational process at primary school.

The analysis of the coefficients of variation points to heterochrony in the development of the 9-year-old girls' motor abilities. The level of proficiency in gymnastic exercises indicates that the exercises are impossible for 9-year-old girls to perform. Based on the data analysis, it can be argued that the development of "arm strength" and "vestibular stability" ensures the formation of motor skills, and the improvement of their development level is the reserve in training girls aged 9 which will positively influence the educational process effectiveness.

The obtained results supplement the data on the relationship between the level of proficiency in physical exercises and

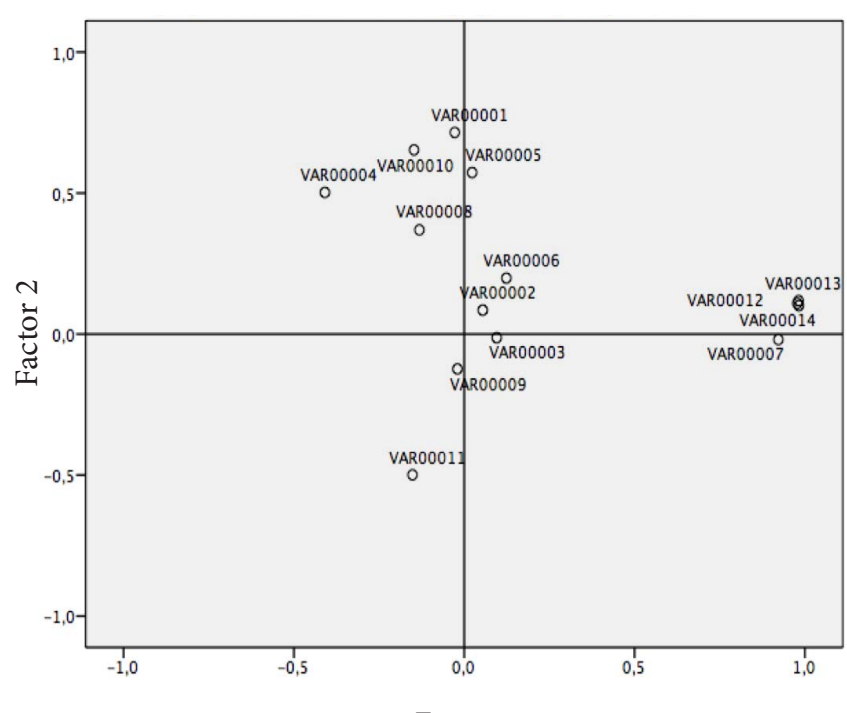

Factor 1

Fig. 1. The graphic representation of a two-factor model of testing results: 1 - height $(\mathrm{cm}), 2$ - body weight $(\mathrm{kg}), 3$ - "Standing long jump (cm)", 4 - "Middle- and long-distance running. $300 \mathrm{~m}$ running (s)", 5 - "30 m sprint running from a standing start (s)", 6 - "Seated forward bend (cm)", 7 - "Mixed hang rope pull-ups (times)", 8 - "Shuttle run $4 \times 9 \mathrm{~m}$ (s)", 9 - "Combined movements of arms, torso and legs (points)", 10 - "Maintenance of stable posture - standing on one leg with closed eyes (s)", 11 - "Walking along straight line after 5 rotations (deviations in $\mathrm{cm}$ )", 12 - "Rope climbing in two steps, level of proficiency". 13 - "Rope climbing in three steps, level of proficiency", 14 - "One leg swing upward circle, level of proficiency"

the level of motor abilities development (Ivashchenko, Berezhna, \& Cieślicka, 2020; Ivashchenko \& Sirichenko, 2020).

The results of factor analysis confirm the integrity of the process of motor skills formation and motor abilities development in children and supplement the data of Khudolii, Ivashchenko, and Chernenko(2015); Ivashchenko, Iermakov, Khudolii, Cretu, and Potop (2017). 
The study results highlight the need to select teaching techniques taking into account the peculiarities of motor abilities development (Ivashchenko, Khudolii, Iermakov, Chernenko, \& Holovko, 2015), the educational process organization (Hellin, Gar cia-Jimenez,\& Garcia-Pellicer, 2019a; Hellin, Garcia-Jimenez,\& Garcia-Pellicer, 2019b; Groffik, Mitáš, Jakubec, Svozil,\& Frömel, 2020), and optimization of exercise modes (Ivashchenko \& Cieślicka. 2017); Cieślicka \& Ivashchenko, 2017; Marchenko \& Kovalenko. 2020).

Thus, the motor fitness of 9-year-old girls is determined by the level of development of arm strength, vestibular stability, and the level of proficiency in gymnastic exercises.

\section{Conclusions}

Based on factor analysis, it was found that the level of proficiency in exercises determines the variation of testing results by $28.394 \%$, and the development of motor skills is a priority in the educational process at primary school.

The level of proficiency in gymnastic exercises shows that the exercises "Rope climbing in two steps", "Rope climbing in three steps", "One leg swing upward circle" are difficult for 9 -year-old girls to perform. Based on the data analysis, it can be argued that the development of "arm strength" and "vestibular stability" ensures the formation of motor skills, and the improvement of their development level is the reserve in training girls aged 9 which will positively influence the formation of motor skills.

\section{Acknowledgement}

The study was carried out in accordance with the plan of research work of the Department of Theory and Methodology of Physical Education of H. S. Skovoroda Kharkiv National Pedagogical University.

\section{Conflict of Interests}

The authors declare no conflicts of interest.

\section{References}

Krutsevych, T., \& Marchenko, O. (2018a). Modeli tsinnisnykh oriientatsii u povedinkovykh kharakterystykakh osobystosti shkoliariv riznykh vikovykh hrup. Sportyvnyi visnyk Prydniprovia, (2), 57-64. http://infiz.dp.ua/misc-documents/2018-02/2018-02-10.pdf

Krutsevych, T., \& Marchenko, O. (2018b). Struktura modeli tsinnisnykh oriientyriv indyvidualnoi fizychnoi kultury shkoliariv riznykh vikovykh hrup. Slobozhanskyi naukovosportyvnyi visnyk, (5 (67)), 5-10. https://doi.org/10.15391/snsv.2018-5.001

Krutsevich, T., Pengelova, N., \& Trachuk, S. (2019). Modeltarget characteristics of physical fitness in the system of programming sports and recreational activities with adolescents. Journal of Physical Education and Sport, 19, 242-248. Scopus. https://doi.org/10.7752/jpes.2019.s1036

Junger, J., Salonna, F., Bergier, J., Junger, A., Frömel, K., Ács, P., \& Bergier, B. (2019). Physical activity and bodymass-index relation in secondary-school students of the visegrad region. Journal of Physical Education and Sport, 19, 235-241. https://doi.org/10.7752/jpes.2019.s1035
Haverkamp, B. F., Wiersma, R., Vertessen, K., van Ewijk, H., Oosterlaan, J., \& Hartman, E. (2020). Effects of physical activity interventions on cognitive outcomes and academic performance in adolescents and young adults: A meta-analysis. Journal of Sports Sciences. Scopus. https://doi.org/10.1080/02640414.2020.1794763

Kondakov, V. L., Voloshina, L. N., Kopeikina, E. N., \& Kadutskaya, L. (2020). Daily assessment of physical activity in 6-11-year-old children. Journal of Physical Education and Sport, 20(4), 1673-1680. Scopus. https://doi.org/10.7752/jpes.2020.04227

Quaney, B. M., Boyd, L. A., McDowd, J. M., Zahner, L. H., He, J., Mayo, M. S., \& Macko, R. F. (2009). Aerobic exercise improves cognition and motor function poststroke. Neurorehabilitation and neural repair, 23(9), 879-885. https://doi.org/10.1177/1545968309338193

Khudolii, O., Kapkan, O., Harkusha, S., Marchenko, S., \& Veremeenko, V. (2020). Motor Skills Development: Optimization of Teaching Boys Aged 15 Press Headstand and Handstand. Teoriâ ta Metodika Fizičnogo Vihovannâ, 20(1), 42-48. https://doi.org/10.17309/tmfv.2020.1.06

Ivashchenko, O., Khudolii, O., Prusik, K., \& Giovanis, V. (2020). Strength Abilities: Immediate and Delayed Training Effects of Orthogonal Modes of Strength Training in Boys Aged 8 Years. Teoriâ ta Metodika Fizičnogo Vihovannâ, 20(2), 109-116. https://doi.org/10.17309/tmfv.2020.2.07

Khudolii, O. (2019). Research Program: Modeling of Young Gymnasts' Training Process. Teoriâ ta Metodika Fizičnogo Vihovannâ, 19(4), 168-178. https://doi.org/10.17309/tmfv.2019.4.02

Ivashchenko, O. (2020). Research Program: Modeling of Motor Abilities Development and Teaching of Schoolchildren. Teoriâ ta Metodika Fizičnogo Vihovannâ, 20(1), 32-41. https://doi.org/10.17309/tmfv.2020.1.05

Ivashchenko, O., Berezhna, H., \& Cieślicka, M. (2020). Motor Skills in the Structure of Physical Fitness of 7-Year-Old Boys. Journal of Learning Theory and Methodology, 1(1), 14-19. https://doi.org/10.17309/jltm.2020.1.02

Ivashchenko, O., \& Sirichenko, D. (2020). Structure of Motor Fitness of 7-Year-Old Girls. Journal of Learning Theory and Methodology, 1(1), 20-25. https://doi.org/10.17309/jltm.2020.1.03 (in Ukrainian)

Marchenko, S., \& Kovalenko, K. (2020). Optimization of Teaching Boys Aged 10 Mae-Geri (Front Kick) Technique in Kyokushin Karate. Journal of Learning Theory and Methodology, 1(1), 33-39. https://doi.org/10.17309/jltm.2020.1.05 (in Ukrainian)

Ivashchenko, O., Khudolii, O., Iermakov, S., Chernenko, S., \& Holovko, A. (2015). Pedagogical Control of Motor Readiness of Junior School Boys. Teoriâ ta Metodika Fizičnogo Vihovannâ, (2), 32-40. https://doi.org/10.17309/tmfv.2015.2.1140 (in Ukrainian)

Ivashchenko, O., Iermakov, S., Khudolii, O., Cretu, M., \& Potop, V. (2017). Level of physical exercises' mastering in structure of 11-13 yrs age boys' motor fitness. Pedagogics, Psychology, Medical-Biological Problems of Physical Training and Sports, 21(5), 236-243. https://doi.org/10.15561/18189172.2017.0506

Khudolii, O., Ivashchenko, O., \& Chernenko, S. (2015). Simulation of junior shcoolchildren's training to acrobatic exercises and vaults. Pedagogics, Psychology, MedicalBiological Problems of Physical Training and Sports, 19(7), 64-71. https://doi.org/10.15561/18189172.2015.0709

Ivashchenko, O., \& Cieślicka, M. (2017). Features of evaluations of power loadsin boys 7 years old. Journal of Education, Health and Sport, 7(1), 175-183. http://dx.doi.org/10.5281/zenodo.249184 
Cieślicka, M., \& Ivashchenko, O. (2017). Features of formation of the cumulative effect of power loads in boys 7 years old. Journal of Education, Health and Sport, 7(1), 198-208. http://dx.doi.org/10.5281/zenodo.250599

Hellin, M., Garcia-Jimenez, J. V., \& Garcia-Pellicer, J. J. (2019a). Intensity of physical education lessons in children according to the type of activity: Soccer, badminton, aerobics and motor skills. Journal of Physical Education and Sport, 19(1), 603-610. Scopus. https://doi.org/10.7752/jpes.2019.01088

Hellin, M., Garcia-Jimenez, J. V., \& Garcia-Pellicer, J. J. (2019b). Intensity of physical education lessons in children according to the type of activity: Soccer, badminton, aerobics and motor skills. Journal of Physical Education and Sport, 19, 148-155. Scopus. https://doi.org/10.7752/jpes.2019.s1022

Groffik, D., Mitáś, J., Jakubec, L., Svozil, Z., \& Frömel, K. (2020). Adolescents' Physical Activity in Education Systems Varying in the Number of Weekly Physical Education Lessons. Research Quarterly for Exercise and Sport. Scopus. https://doi.org/10.1080/02701367.2019.1688754

\title{
ОСОБЛИВОСТІ СТРУКТУРИ РУХОВОЇ ПІДГОТОВЛЕНОСТІ ДІВЧАТОК 9 РОКІВ
}

\author{
Олег Худолій ${ }^{1 \mathrm{ABCD}}$, Владислав Головнін ${ }^{1 \mathrm{ABCD}}$, Павол Бартік ${ }^{2 \mathrm{ABCD}}$ \\ ${ }^{1}$ Харківський національний педагогічний університет імені Г. С. Сковороди \\ ${ }^{2}$ Університет Матея Беля \\ Авторський вклад: А - дизайн дослідження; В - збір даних; C - статаналіз; D - підготовка рукопису; Е - збір коштів \\ Реферат. Статья: 5 с., 2 табл., 1 рис., 22 джерела.
}

\begin{abstract}
Мета дослідження - визначити особливості структури рухової підготовленості дівчаток 9 років.

Матеріали і методи. У дослідженні прийняли участь 35 дівчаток 9 років. Діти та їхні батьки були інформовані про всі особливості дослідження і дали згоду на участь в експерименті. У дослідженні використані такі методи дослідження як аналіз наукової та методичної літератури, педагогічні спостереження, тестування рухової підготовленості, ймовірнісний підхід до оцінки процесу навчання, методи математичної статистики.
\end{abstract}

Результати. За рівнем підготовленості дівчатка 9 років $є$ однорідними за розвитком «прудкості» $\mathrm{i}$ «координації рухів», неоднорідними - за розвитком гнучкості, сили рук і вестибулярної стійкості, рівнем навченості гімнастичних вправ. Графічне відображення двохфакторної моделі результатів тестування дає уявлення про те, що в аналізі виділяються з високими коефіцієнтами кореляції дві плеяди даних. У першу плеяду включені тести No 12, 13, 14 і 7, які характеризують рівень навченості гімнастичних вправ та відносну силу м'язів рук; у другу - тести No 1, 10, i 5, які характеризують рівень розвитку координації рухів.

Висновки. На основі факторного аналізу встановлено, що рівень навченості вправам на $28.394 \%$ визначає варіацію результатів тестування, а формування рухових навичок має пріорітет в освітньому процесі у молодшій школі.

Рівень навченості гімнастичних вправ свідчить про те, що вправи лазіння по канату у 2 прийоми, лазіння по канату у 3 прийоми, підйом переворотом в упор махом однією є мало доступними для дівчаток 9 років. На основі аналізу даних можна стверджувати, що розвиток «сили рук» $\mathrm{i}$ «вестибулярної стійкості» забезпечує формування рухових навчок, а підвищення рівня їх розвитку $є$ тим резервом у підготовці дівчаток 9 років який дозволить позитивно впливати на формування рухових навичок.

Ключові слова: дівчатка 9 років, рівень навченості, рухова підготовленість, рухові навички.

\section{Information about the authors:}

Khudolii Oleg: khudoli@hnpu.edu.ua; http://orcid.org/0000-0002-5605-9939; H. S. Skovoroda Kharkiv National Pedagogical University, Department of Theory and Methodology of Physical Education, Alchevskykh St, 29, Kharkiv, 61002, Ukraine.

Golovnin Vladyslav: golka140993@gmail.com; https://orcid.org/0000-0001-7070-8539; H. S. Skovoroda Kharkiv National Pedagogical University, Department of Theory and Methodology of Physical Education, Alchevskykh St, 29, Kharkiv, 61002, Ukraine.

Bartík Pavol: pavol.bartik@umb.sk; https://orcid.org/0000-0002-2087-7876; Department of Physical Education and Sports, Matej Bel University. Tajovského 40, 97401 Banská Bystrica, Slovakia.

Cite this article as: Khudolii, O., Golovnin, V., \& Bartik, P. (2020). Peculiarities of Motor Fitness Structure of 9-Year-Old Girls. Journal of Learning Theory and Methodology, 1(2), 53-57. https://doi.org/10.17309/jltm.2020.2.01

Received: 27.08.2020. Accepted: 20.10.2020. Published: 30.10.2020

This work is licensed under a Creative Commons Attribution 4.0 International License (http://creativecommons.org/licenses/by/4.0). 